\title{
SOUTH AFRICA'S STRATEGIC ARMS PACKAGE: A CRITICAL ANALYSIS
}

\author{
Justin Sylvester and Prof Annette Seegers \\ University of Cape Town
}

\begin{abstract}
The South African government's Strategic Arms Package (SAP), has been the largest public controversy of the post-Apartheid era. We synthesise the debates about two dimensions of the SAP, military necessity and affordability, in order to get a better understanding of civil-military relations in democratic South Africa. Our synthesis shows that the economic enthusiasm about the SAP is both naïve and an opportunity for government and dominant business and industry to wed their interests in a way that is not that different from the Apartheid era. In military terms, the SAP has equipped the South African Air Force (SAAF) and South African Navy (SAN) for the most improbable of primary missions. The equipment is also not very relevant to secondary missions. The way that the SAP decisions were reached suggests that civil-military relations are marked by the continuing impact of past compromises, corruption and the centralisation of power in the executive branch.
\end{abstract}

\section{Introduction}

This article ${ }^{1}$ presents a critical analysis of the South African government's Strategic Arms Package (SAP), commonly known as the Arms Deal. ${ }^{2}$ In 1999, the South African government (SAG) entered into an SAP of over R29 billion. At that stage, the SAP consisted of five main contracts. The German Submarine Consortium (GSC) was to supply four submarines to the SAN at a total cost of R4 289 million. The Italian company, Augusta, was awarded the right to supply 30 utility helicopters to the SAAF at R1 532 million. The lead-in fighter trainer (LIFT) contract was awarded to British Aerospace (BAE), who was going to provide the SAAF with 24 Hawk fighter/trainer jets to the amount of R3 728 million. The contract for four

\footnotetext{
${ }^{1}$ This article is based, in large part, on Sylvester (2006). We are indebted to the comments and suggestions of the examiners. All errors are ours.

${ }^{2}$ The terms Arms Deal and Strategic Arms Package will be used interchangeably.
} 
corvettes was awarded to the German Frigate Consortium-Thomson (GFCT) at R5 473 million, and the advanced light fighter aircraft (ALFA) contract was granted to British Aerospace to supply $28 \mathrm{SAAB}^{3}$ Gripen fighters at the total price of R9 952 million (Crawford-Browne 2004:12). These contracts were lumped together into a "package" intended to provide a more affordable deal for the SAG.

The Arms Deal has attracted fierce and sustained criticism from all quarters of South African society, and has lead to a series of court cases. The legal action continues involving, among others, the President of the African National Congress, Jacob Zuma. The cost of the SAP, mostly financed through an intricate set of loans from foreign banks, was staggering. Worse, the 1999 Arms Deal focused only on the air force and navy; army-acquisitions are to follow some time in the future (February 2004:9).

Here we concentrate on two aspects of the SAP: necessity and affordability. The point of our discussion is to ask what these issues show about civil-military relations in democratic South Africa. ${ }^{4}$ The methodology involved is qualitative and synthesises an existing debate along thematic lines, in order to bring some clarity to a controversial subject.

\section{Definitions}

Acquisition here refers to any and all actions taken in satisfying the need for military material, facilities and/or logistics. Procurement is a narrower concept, referring to the actual contracting for the satisfaction of any of these requirements.

MILEX refers to expenditure on the day-to-day running costs of the Department of Defence, including the remuneration of personnel and maintenance of property. These items are already in the inventory of a military.

Arms Research, Development and Production expenditure refers to funds set aside for the research, development and production of armaments and military equipment. These armaments and equipment may be procured domestically or from foreign sources.

${ }^{3}$ British Aerospace (BAE) has a 50 percent share in the Swedish SAAB company.

${ }^{4}$ Because most of the legal action is still in motion, we do not discuss issues of corruption and the individuals who may be involved. For more detail see Feinstein (2007:154-236). 


\section{4}

Arms Acquisition refers to routine expenditure on the acquisition of military equipment. This is usually the responsibility of the chief accounting officer of the defence department and, in turn, the political head of the defence department (a minister, for example). This expenditure can be of a non-cardinal nature or, because of price, may be considered a routine expenditure.

Strategic Arms Acquisition differs from routine arms purchases in that it refers to very rare and very expensive acquisitions and thus becomes the responsibility of a country's executive and/or legislative branches of government. When a series of arms acquisition programmes are, for various reasons, packaged into one cardinal expenditure programme, it becomes a non-routine or strategic expenditure.

Offset Agreements are used by arms companies to add incentives for possible buyers to award them arms contracts. Offsets are also used to compensate the purchasing state for the loss of work within the country. There are two kinds of offset agreements. One involves a counter-purchase where the foreign supplier company agrees to buy components from local manufacturers in exchange for the right to supply the required hardware (Wrigley 2003:1). The other is found where the foreign supplier agrees to invest in the local economy, especially within the arms industry. Offsets are sometimes known as industrial participation programmes in the international defence industry.

\section{Actors and policies}

The SA Defence Secretariat is responsible for all acquisition activities. The Secretariat's main function is to ensure the best value for money and that the expenditure falls within the financial constraints of the defence budget as well as the overall financial objectives of the state (RSA 1996a:14).

In the Defence Secretariat, the Defence Secretary is the chief accounting officer $^{5}$ of the Department of Defence (DoD). He/She is also responsible for formulating DoD policy. Within the Defence Secretariat is an Acquisitions Division, headed by the Chief of Acquisitions, who is responsible for industrial and procurement policy for the DoD and for coordinating research and technology. The Chief of Acquisitions reports to the Defence Secretary (RSA 1996a:7).

\footnotetext{
${ }^{5}$ Accounting Officer refers to a position where the official is responsible for all expenditure within the relevant department.
} 
The Defence Secretary chairs an Armament Acquisition Steering Board (AASB). This Board, which includes members from the Secretariat and the SA National Defence Force (SANDF), approves non-cardinal projects and screens cardinal acquisition projects. It is policy that the Secretariat should grant contracts at the highest possible level, in other words, the Secretariat (for the DoD) does not deal with sub-contracted suppliers (RSA 1996a:8, 51). This point will be very important within the context of the Strategic Arms Package.

The SANDF is headed by the Chief of the South African National Defence Force (CSANDF), who enjoys executive command over the SANDF under the direction of the Minister of Defence in peacetime, and the President during national emergencies. It is the task of the CSANDF to implement defence policies, planning and administrative directives of the Ministry of Defence (MoD) (Frankel 2000:106108).

The SANDF determines its own arms requirements, provided that these are in line with the approved force structure, defence policies, programmes and budgets of the MoD, the Secretariat and Parliament. The SANDF is responsible for the overall management of armament acquisition projects, thus ensuring that defence systems are in line with stated requirements. In the SANDF, the Chief of Logistics chairs an Armament Acquisition Control Board (AACB). The AACB screens acquisition projects according to the stated requirements of the SANDF (RSA 1996a:7-8) (See Figure 1).

ARMSCOR $^{6}$ manages all acquisition processes for the DoD, including management of programmes, tenders and the awarding of contracts, and:

... ensures that the technical, legal, and financial integrity of companies supplying acquisitions are in accordance with DoD requirements. Additional tasks include offering marketing support for the industry, facilitating participation in international armaments shows, and the co-management of Industrial Participation Programmes with the Department of Trade and Industry (DTI) (RSA 1996a:5).

\footnotetext{
${ }^{6} \mathrm{SA}$ 's arms conglomerate, created in the $1960 \mathrm{~s}$.
} 




Figure 1: Department of Defence AAAS

After restructuring in 1992, ARMSCOR became ARMSCOR/DENEL, still a statutory and a state-owned company (RSA 1996a:9). ARMSCOR remained under the MoD and retained its core function of arms procurement on behalf of the DoD. DENEL took control of the domestic defence industry, falling under the Ministry of Public Enterprises. The chairperson of ARMSCOR is a member of the Defence Planning Committee, chaired by the Minister of Defence (Zacarias 1998:4-5). 


\section{7}

What arms does ARMSCOR procure for the DoD? The DoD seeks limited self-sufficiency in certain areas. For example, instead of trying to produce largescale weapon systems (say, fighter jets and tanks) locally, these systems can be bought internationally but with the proviso that the domestic industry produces (say) ammunition for the system. When a system is bought abroad, the idea is to maximise the domestic producers' participation and to secure a transfer of technology. Counter-trade agreements are the norm for all foreign procurement of defence systems. The DoD wishes to encourage competition for contract tenders so as to ensure the best deals available. Tenders are supposed to be awarded on the basis of value for money and life cycle costs of the defence systems to be procured (RSA 1996a:5, 7).

Most of the actual arms production in SA is done under the auspices of DENEL, the state asset expected to compete internationally like any profit-seeking commercial enterprise (RSA 1996a:6). DENEL, along with other defence companies Reunert, Altech, Plessy and Grineker, account for 90 percent of the domestic industry's capital expenditure. By 1997, arms had become SA's second largest manufactured export, although it accounts for less than 1,2 percent of GDP and only one percent of manufacturing jobs in South Africa (Shelton 1998:2).

In the case of non-routine or strategic arms projects, the political approval of

the President and Cabinet is required. This approval is overseen by Parliament's Joint Standing Committee on Defence (RSA 1996a:51).

In the Executive, the Presidency, including the Deputy President, has a limited, but very important role to play within SAP programmes. In order for (say) DENEL to lower the cost of production, production must be increased. With the SANDF unable to stretch its needs so far, the Presidency plays a role in encouraging overseas clients to "buy South African". In a tight arms market, South Africa's ability to peddle its wares, like the Rooivalk attack helicopter and the Rooikat armoured car, is dependent on marketing, and the Presidency is seen as an important cog in the marketing machine (Shelton 1998:6). Government has a direct interest in arms export gaining foreign exchange and other technology (RSA 1996a:19); arms acquisition thus becomes a form of economic foreign policy. 


\section{8}

The Executive was an active, if not dominating ${ }^{7}$, participant in the SAP, negotiating directly with foreign governments like Britain and Germany, who are South Africa's main European trade partners and source of FDI (foreign direct investment). The SAP was a means to attract FDI and to gain access to foreign markets.

In the Executive, responsibility for routine/non-cardinal arms acquisition rests with the Minister of Defence in the Ministry of Defence. For non-routine acquisitions, the Minister chairs an Armament Acquisition Council (AAC). AAC membership includes the Defence Secretary, the CSANDF and the Executive General Manager of ARMSCOR. The AAC approves armament acquisition policy, approves all armament acquisition budgets and approves all cardinal projects (RSA 1996a:7, 25).

All major arms procurement and acquisitions must have the approval of Parliament (RSA 1996b:Chapter 7, par. 5). Here the Portfolio Standing Committee on Defence (PSCD) of the National Assembly is mandated to monitor, investigate and enquire into matters and decisions related to defence policy (Le Roux and Boshoff 2005:189). Although not mandated to deal with defence legislation, the constitution-based Joint Standing Committee on Defence (JSCD) enjoys broad powers of oversight and has wide-ranging powers of investigation. The JSCD includes members of the National Assembly ${ }^{8}$ and the National Council of Provinces. Although other parliamentary bodies share in overseeing the acquisition process of the DoD, it is the JSCD that is supposed to play the main oversight role in this regard. One of the main problems the committee has faced is the high rate of turnover among members, members' limited expertise, and insufficient research support. Despite its effort, the JSCD often lags behind the SANDF in understanding defence issues (Mills 1999:3; Frankel 2000:70, 120).

\section{Parliament's Standing Committee on Public Accounts (SCOPA) is} responsible for the DoD's external audit. In reality, this function is performed by the office of the Auditor-General who in turn reports to SCOPA. SCOPA does not deal with policy or legislation, but focuses solely on public expenditure by government, assessing the efficiency and effectiveness of government's management of state finances, and checking whether government departments' expenditure is in line with

7 The Hawk, for instance, was chosen against the preference of the Secretary of Defence and the Chiefs of the SAAF, as government was keen to grant a major contract to the British arms company (Crawford-Browne, 2004:1).

${ }^{8}$ If the relevant party obtains more than 10 seats in the National Assembly. 
their budgets. The DoD and its arms acquisitions fall directly within the ambit of financial oversight by SCOPA. However, as we shall see, SCOPA's reputation was tarnished by the Arms Deal (February 2004:4).

The National Conventional Arms Control Committee (NCACC) was established on the recommendation of the Cameron Commission of Inquiry into ARMSCOR's role in a proposed sale of armaments to Lebanon in 1994 (the Wazan debacle). The idea was that the NCACC would have powers of consent over all armament exports and imports for the use of the SANDF. The White Paper on Defence 1996 outlines the scope and nature of the NCACC's work. As a statutory body, however, the NCACC dates from 2000, almost one year after the SAP had been signed by Cabinet. The NCACC has two functions. The first is to oversee the acquisition, procurement and export of all arms. The second is to design arms acquisition policies for the SANDF. Furthermore, the NCACC is charged with evaluating all applications for arms-related research, development, manufacturing, marketing and contracting and it also grants permits for these activities (Skosana 2002:1, 9). If these functions are to be taken seriously, it begs the question why the SAP was not approved by the NCACC (Mills 1999:4).

\section{The Context of the SAP}

The Defence Review process of 1998, a wide-ranging consultation amongst South African society on defence policy, set the ball rolling for the SAP (RSA 1998). As the Review split into different working groups, NGOs and human rights activists produced very progressive policies in terms of the rights of women and homosexuals. On the more technical military issues, however, few civilians were present and activists were outsmarted by the soldiers. The soldiers were thus not subjected to much scrutiny, especially when it came to the formulation of the SANDF's force design (Cawthra n.d.:5). In the end, the JSCD was presented with four possible options regarding the design and structure of the SANDF: (See Table $1)$.

The Defence Review reaffirmed the commitment of the 1996 White Paper on Defence to a "strategic defensive posture", but included the ability to mount offensive operations with the use of conventional forces in order to repel any external attack from a similar military power. To maintain such a capability, the Review chose the option whereby the SANDF would retain a core conventional force (that is, corvettes and fighter jets) which could be rapidly expanded in times of crises (Cawthra 2000:15). The Review rejected the notion that SA needed self- 


\section{0}

sufficiency in its arms requirements, except in key areas. Instead, the SANDF should maximise the use of local suppliers. All platform suppliers ${ }^{9}$ were to be responsible for the sub-contracting of suppliers of subsystems (Zacarias 1998:5) (See Table 1).

Table 1. Options on the design and structure of the SANDF.

\begin{tabular}{|l|c|c|c|c|}
\hline & Option 1 & Option 2 & Option 3 & Option 4 \\
\hline $\begin{array}{l}\text { Total cost SANDF } \\
(\text { Rm) }\end{array}$ & 5010 & 6014 & 4084 & 5912 \\
\hline Personnel & & & & \\
\hline Full-time & 22000 & 36000 & 26200 & 27200 \\
\hline Part-time & 69400 & 98000 & 77900 & 82000 \\
\hline Light fighters & 32 & 32 & & 44 \\
\hline Transport helicopters & 96 & 96 & 48 & 64 \\
\hline Submarines & 4 & 4 & & 4 \\
\hline Corvettes & 6 & 6 & 8 & 6 \\
\hline
\end{tabular}

(RSA 1998:44)

There was much criticism of the Review, even at the time of its approval by Parliament. The Institute for Security Studies (ISS) argued against the emphasis on the SANDF's conventional ability, noting that the SANDF was more likely to be involved in its secondary missions such as peace operations and assisting the South African Police Service (SAPS) (ISS 2004:1). For others, the emphasis on the primary mission by conventional means reflected a desire to re-equip and re-arm the SANDF (Ferreira and Liebenberg 2004:74).

Regardless of the intentions of the participants at that time, there is no doubt that the Defence Review became a legitimating mechanism for the SAP. Supporters of the SAP say that, because Parliament has approved the Defence Review, it had approved the SAP itself. This cannot be the case. One reason is that Parliament approved a document containing several options. A second reason is that what Parliament had approved was an ideal image of the SANDF force design, subject to

9 Platform here refers to a single unit of military hardware i.e., a fighter jet or a corvette. Previously, various parts of a platform would have been sourced from different suppliers or developed "inside", thus generating home-grown platforms. 


\section{1}

budgetary constraints (February 2004:3). A third reason is that, since the Review did not include details about the exact cost of the various options to the state's budget, Parliament could not have been in an informed position to approve expenditure (Ferreira and Liebenberg 2004:77).

Lobbying by the SAN to acquire a blue water fleet had begun as early as 1994. Then Minister of Defence, Joe Modise, approached Parliament with a request to acquire corvettes from a Spanish company, Bazan. His request was ignored as the new JSCD replied that the very legitimacy of the SANDF had to be assessed before any acquisitions could be approved (Modise 2004:45). This refusal by the JSCD sparked the Defence Review process. By 1997 the Minister had placed the issues of corvettes back on the agenda and by that time it was clear that the DoD was far into negotiations with German and French consortiums as possible suppliers of the corvettes - long before the Defence Review had even been approved by Parliament. Throughout the Review process, the Germans had apparently been lobbying various members of the working groups and had been wining and dining influential members within the JSCD (Ferreira and Liebenberg 2004:72).

Local advocates of the SAP, most of all the SAN, were doing their own intense lobbying. The sailors were very successful at lobbying influential MPs, arguing that their equipment was obsolete. Eventually, the scales were tipped by the promise of creating an estimated 65000 jobs and possible offsets of over R100 billion pumped into a struggling economy (Nathan 2005:369). For government, an SAP was an opportunity to sort out the defence industry. By the mid-1990s, the industry had become a financial liability but offsets offered a way of rationalisation: unprofitable arms companies could be sold to naïve investors and foreigners, and profitable ones retained (February 2004:2).

Four committees were established to consider the various tenders: a technical committee, a finance merit committee, a defence industrial participation (DIP) committee, and a national industrial participation committee. Tenders were given marks out of 300. All results were given to the coordinating Strategic Offers Committee for consideration, who in turn submitted its results to the Armament Acquisition Steering Board (AASB). Recommendations were then forwarded to the Armaments Acquisition Council (AAC). The AAC reported to the Minister's Committee, chaired by then Deputy President Thabo Mbeki, who in turn reported to Cabinet. By December 1999, government announced that it had signed agreements with various suppliers to re-equip the SANDF, with the SAN and the SAAF being the chief beneficiaries of the SAP (February 2004:9-13). 


\section{Analysing the SAP}

\section{Military necessity?}

The SA Constitution, White Paper on Defence and the Defence Review state that the SANDF has a primary function of defending SA's territorial integrity and its people. This view emerged primarily in response to the fear that the SANDF would involve itself in domestic political matters (Nathan 2001). However, the wording of the SA Constitution can be decontextualised to show that defence means defence by military and conventional means and deterring enemies by showing them an overpowering conventional capability. Thus buying significant numbers of conventional arms is legal. To be legitimate besides legal, however, requires credibility - sadly lacking - about the imminent and conventional threats to a militarily vulnerable SA.

Apart from the de jure argument, the purchase of conventional equipment also has to be squared against the de facto nature of the SANDF's de jure and de facto activities. Most of the time, the SANDF is quite legally and legitimately involved in secondary functions, notably peace and/or police support operations, for which its conventional capability is ill suited. Corvettes and utility helicopters may be necessary but definitely not fighter jets and submarines.

The SAP's submarines and the jet fighters have provided much ammunition for critics of the SAP. Does the SAP equipment help to protect the coastal economic zones of SA? SA's White Paper on Defence (1996) fully embraces a wide notion of security, accepting the view that security challenges are not primarily military by nature, indeed they are not even interstate affairs. This does not mean that military spending would increase; on the contrary, spending on civilian priorities would increase (Nathan 2001). Moreover, why should the military dominate every aspect of security? Harris argues that this would amount to "mission creep", for example, whereby the corvettes are to be used to protect the coastal economic zones of the Southern African coast. Privatising this function or mandating another government department would be more cost-effective. Harris points out that the Department of Environmental Affairs and Tourism has launched three inshore patrol vessels and one deep-sea patrol vessel to guard South Africa's exclusive economic zone. The cost of these vessels totalled R500 million whilst the Meko class corvettes come with a price tag of R6,9 billion. In the long term, the cost of the corvettes will be more than double that amount (Harris 2000:4-24). 


\section{3}

The fighter jets will afford the SAAF some measure of power over SubSaharan African skies. South Africa is bordered to the north by economically dependent countries that have no incentive to threaten South Africa's sea or airspace by conventional means. To the east, south and west are expanses of ocean. The only African countries that possess submarines are Algeria, Egypt and Libya, all operating in the Mediterranean Sea (Engelbrecht 2001b). Even if one were to accept the claim that South Africa should retain the conventional capability to repel possible external aggression, the submarines and fighter jets seem to be an extravagance. Even worse, the SAP may well contribute to a regional arms race and the corvettes, submarines and jet fighters may be regarded as offensive" weapons that are contrary to South Africa's foreign policy of co-operative defence with its neighbours (Williams 2005:10).

SA's foreign policy is noted for its African bias. An energetic debate exists in terms of this bias, with some scholars arguing that African Renaissance and NEPAD policies conceal a selfish and perhaps materialistic desire to dominate the continent and to control migration to and from SA (Patel 2006). Others maintain that SA is the best hope for African conflicts to be peacefully resolved and that SA can be involved in peacemaking, as successive presidents and public figures already have been, and help in the implementation of agreements. For peacekeeping and especially the logistical and others serious military demands of regional peace operations, a well-equipped, modern and technologically advanced SANDF gives SA much clout in African and international organisations (Jacobs and Calland 2002; Landsberg and Adebajo 2003).

In SA, the military necessity discourse is based on the Constitution. This can be compared to the American Constitution, which requires the maintenance of a navy. However, this still begs the questions: How big a navy and What kind of navy? Many critics would agree that SA's air and naval services deserved, after decades of sanctions, some rearmament. Critics cannot accept, however, the nature and size of the rearmament as being militarily necessary.

\section{Affordability of the SAP: Considering alternatives and offset arrangements}

\section{Alternatives}

Some observers accept the necessity of the SAP items but question the affordability of the particular contracts - most notably the Hawk Trainer contract. The South African government has received even greater criticism as to the 
financing of the deal itself. Many have argued that the SAP has placed South Africa in a precarious financial position, as government had to undertake loans from foreign banks in order to finance the SAP.

David Botha (2003: 45) argues that the SAP, as a percentage of the GDP, is well below international norms. The Defence Review of 1998 accepted that $1,8 \%$ of the GDP was required to pay for acquisitions and operating costs. Botha (2003:4546) adds that the original hardware requirement was even lowered in order to make the SAP more affordable (See Table 2). Of all the tenders that were considered, the final successful contracts were the ones that scored the highest points in terms of performance, price, the industrial participation benefits and available financing.

Nevertheless, the Hawk trainer contract was not the best in terms of price. The Italian-made Aermacchi MB 339, a highly rated machine, was half the price of the Hawk trainer. British Aerospace, however, added a larger amount of offsets to the Hawk tender. The UK offered $\$ 1,2$ billion compared to the $\$ 431$ million on offer from the Italians and this tipped the balance in the favour of the British (Botha 2003a:47). Some argued that, because the Hawk, designed as both a trainer and combat fighter, was only required as a training platform for SAAF recruits, it was an unnecessary option. It was unlikely that the Hawk would be used in a combat role by the SAAF, and thus a cheaper trainer such as the MB339 was a better choice (Wrigley 2003:11)

Table 2: Lowered requirements of the SAP

\begin{tabular}{|l|c|c|}
\hline Equipment & Planned & Actual \\
\hline Gripen & 38 & 28 \\
\hline Hawk & 24 & 24 \\
\hline Corvettes & 5 & 4 \\
\hline Submarines & 4 & 3 \\
\hline Helicopters & 60 & 30 \\
\hline
\end{tabular}

(Botha 2003:45-46)

If this is so, what explains the preference for the Hawk? Wrigley (2003:10) argues that, because the Hawk and the Gripen were both connected to British Aerospace, the South African government saw greater value in choosing the British contract for reasons of foreign policy, despite the Italian, Czech and German tenders 
being cheaper. Seemingly, South Africa's interest would have been to secure the British deal as this would guarantee that a struggling BAE would have been more willing than any other contractor to buy into the local defence industry, thus relieving the South African government of this burden. This has, in fact, transpired since the SAP was signed. Miller (1996:5) argues that these are tactics central to attempts by Britain's defence industry to increase its arms exports, with the endorsement of the British government. These tactics include:

A willingness to facilitate offset deals; the use of aid in underwriting arms sales; and the provision of a subsidy for sales to developing countries in the form of disproportionate amounts of credit for military, as opposed to civil, exports.

The arms exporters receive assistance from the British government through the Defence Export Services Organisation (DESO). This organisation advises companies on markets and facilitates access to overseas decision-makers (Miller 1996:5). Thus, political and economic interests were very influential in the success of the BAE tender for the LIFT contract.

The importance of political and economic interests are supported by analysts who argue that the Russians were willing to provide a package deal that consisted of MIG jet fighters, training aircraft and submarines at a much cheaper price (Ferreira and Liebenberg 2004:77). One can only assume that the Russian bid received a lukewarm reception from the South African government because the Russian Federation is outside of the Western European economic club, as well as being less attractive in terms of offset arrangements. The main suppliers are Germany, Britain, Italy and Sweden - all Western European powers and major trading partners of South Africa. At first glance, France seems to be left out. Yet the French company, Thales, has been given the right to provide the electronics for the Westland SuperLynx maritime helicopters that are to serve aboard the corvettes. ${ }^{10}$ These helicopters do not form part of the SAP, but were purchased later. ${ }^{11}$ However, given BAE's substantial offset arrangements with South Africa, such a deal is more likely to be granted to BAE's subsidiary, Vickers. Cheaper alternatives existed to the actual contracts that were signed. The only issues separating these contracts were the promise of more attractive offset arrangements and the South African government's preference for European suppliers (Wrigley 2003:1-11).

${ }^{10}$ By purchasing corvettes, the SA government has bound itself to future purchases of helicopters.

${ }^{11}$ Four Lynx maritime helicopters were purchased and officially deployed on the SAN corvettes from March 2008. 
What about the cost of the SAP in real terms? Its original price (as reported to the public by Cabinet) was a total of R29,9 billion. The price breakdown is shown in Table 3.

Table 3. SAP cost breakdown

\begin{tabular}{|l|l|c|c|}
\hline \multicolumn{1}{|c|}{ Equipment } & \multicolumn{1}{c|}{ Suppliers } & Quantity & Value Rm \\
\hline Corvettes & $\begin{array}{l}\text { German Frigate } \\
\text { Consortium }\end{array}$ & 4 & R5 473 \\
\hline Submarines & Ferrostaal, Germany & 3 & R4 289 \\
\hline $\begin{array}{l}\text { Light utility } \\
\text { helicopters }\end{array}$ & Augusta, Italy & 25 & R1 532 \\
\hline Gripen fighter jets & $\begin{array}{l}\text { SAAB/BAE } \\
\text { Consortium }\end{array}$ & 28 & R9 952 \\
\hline $\begin{array}{l}\text { Hawk Trainer / } \\
\text { Fighter }\end{array}$ & BAE, UK & 24 & R3 728 \\
\hline
\end{tabular}

(Ferreira and Liebenberg 2004: 75)

These totals exclude finance charges, escalation clauses and foreign exchange fluctuations. ${ }^{12}$ The actual cost in real terms will be far higher. Compared to the original cost of R30 billion, the 2004 cost had risen to in excess of R60 billion (February 2004:3). By 2008 it is about R90 billion, by our calculation.

Various committees (described above) evaluated the various bids. In addition, an Affordability Committee (AC) of the Department of Finance assessed the cost of the SAP in the long run and the associated financial and economic risks. The AC reported that on signing the SAP, the government would be committing the state to finance payments up until 2013, which would be a long-term obligation with hidden implications. The AC further emphasised three risks:

First, the Minister's Committee was warned that FOREX rate fluctuations could dramatically increase the costs to the state. Second, the offset arrangements were subject to suspicion as they could not be guaranteed nor strictly enforced.

12 In order to finance the SAP, government agreed to a set of loans from foreign banks that are pegged to the exchange rate. Thus, the more the Rand depreciates to the Dollar, the higher the cost to the state of repaying the loans to these banks. 


\section{7}

Third, it was not possible to understand the full implications of the interest attached to the financing loans. On this, the AC viewed the SAP as having a high level of financial risk to the state with little or no guarantee that the offset arrangements would materialise, thus alleviating the negative impact on the South African economy (February 2004:8). Nonetheless, Cabinet, based on the endorsement of the Minister's Committee, approved the signing of the SAP.

The question remains whether Parliament was informed of the possible financial implications of the SAP for the state. At no point was Parliament made aware of the foreign exchange risks involved with the financing of the SAP. Most MPs were swayed by the promise of job creation and the massive foreign investment that would flow from the deal as a result of offset arrangements. The real costs of the SAP were not made public at the time and government informed both Parliament and the media that the SAP would cost R29,9 billion. It is now known that this was not so (February 2004:9). Even SCOPA stated that Cabinet had been fully aware of the possible financial implications and had a responsibility to inform the public accordingly, which it failed to do (RSA 2000:2).

The financial impact of the SAP on the state's coffers will be enormous. Its bite will be felt in the lack of state capital, among others, for infrastructural maintenance and development and, not least, for poverty alleviation (Mattes 2002:24, February 2004:4). Already - at the very same time as the Arms Deal, in fact - the SAG has claimed that the anti-retroviral drugs so needed by South African HIV/AIDS victims could not be afforded (Feinstein 2007:154).

Its impact will also be felt by the DoD itself. Here armaments and personnel costs have a zero sum relationship; even a small fluctuation in the exchange rate sees more/less funds being made available for personnel costs. Attracting and keeping the best human resources for the military is never easy; it will become even more difficult as the money flows out to the SAP (Le Roux and Boshoff 2005:183-186). If armaments were so vital, why did the DoD not investigate the possibility of secondhand armaments? After the Cold War, the international arms market is flushed with such goods, including corvettes.

\section{Offset arrangements}

One may now well ask, if the SAP was laden with so much cost and risk, why was it approved? Some say the SAP was approved because it would benefit the 


\section{8}

South African economy, yet the offset arrangements are contested ground for advocates and opponents of the SAP.

As stated before, offsets are used by arms companies to provide incentives to the purchasing state and to compensate for the loss of work within a specific country on the arms transfers. Since 1996, South Africa has maintained a mandatory policy of national industrial participation (NIP), intending to use government procurement as a mechanism to create economic and industrial benefits. When government departments and state-owned enterprises procure foreign supplies to the value of $\$ 10$ million, foreign suppliers are obliged to provide offset arrangements in the form of investment into the domestic economy (Botha 2003b:8). ARMSCOR also has a Defence Industrial Participation (DIP) policy that requires offsets for similar value procurement to the benefit of local defence industries (Botha 2003b:1). All NIP projects are managed and monitored by the Department of Trade and Industry (DTI), and DIP is the jurisdiction of the DoD and ARMSCOR (McEwan 2002:4).

Two criticisms are important here. One is the enforceability of the offset agreements, and the other is the question whether such agreements actually alleviate the economic impact of massive expenditures of state funds.

Governments often include certain clauses in offsets agreements that contain a penalty if industrial participation is not forthcoming, but arms companies take this into account and increase the price of the arms transfers accordingly to make up for a possible fine. Moreover, it would be difficult for any government such as that of South Africa to hold an arms company accountable for their IP commitments in a court of law. Within the SAP, the government attached a $10 \%$ of the value of the tender penalty on most contracts. Arms companies could very well just pay the fine and extricate themselves from having to honour their offset commitments. The Apartheid government experienced this when Israel reneged on its offset commitments in the 1970s after having supplied the SAN's Warrior-class fast-attack craft (FAC) (Engelbrecht 2001a:6). To its credit, the SCOPA queried the enforceability of the offsets within the SAP during its public hearings and indicated that the value of the penalties was too small in comparison to the value of the offsets (February 2004:11-12). BAE, hailed as having been the best provider of offsets, combined both the Hawk and Gripen offset projects in order to lessen the amount of investment in the South African economy. SAAB/BAE had up until 2002 only made investments totalling $£ 100$ million out of a promised $£ 1,3$ billion (Leigh 2002). 
Nonetheless, by August 2002, offset arrangements were ahead of schedule, indicating that the arms companies intended to honour their commitments to South Africa. However, Wrigley (2003:13) cautions that, even if all offset commitments are discharged within the allocated period, the quality of the offsets is still up for debate. Many advocates have pointed out that offsets are being honoured and are benefiting the South African economy. Engelbrecht (2001b:2) argues that offsets investments, particularly in the local defence industry, are being discharged and that the SAP offsets have in fact saved many local defence companies from bankruptcy and turned others into profitable concerns. Such companies include Grintek and Denel who have as a result of offsets been offered various contracts to supply Bahrain and Hungary.

Government's arguments for the SAP centred on the benefits, particularly investment, that would accrue to the economy. The creation of 65000 jobs as a result was used as a legitimating instrument for a public concerned about the level of unemployment reaching 40\%. The Coalition of South African Trade Unions (COSATU) responded by saying that even though the SAP and attached offsets have generated employment, this employment has benefited the wrong demography. Unemployment amongst black South Africans is largely attributed to a skills shortage and thus any economic boom within the skills-intensive defence industry is unlikely to impact on this demographic (COSATU 2001:2). COSATU went further to criticise offsets as capital-intensive and benefiting an industry that is predominantly located within Gauteng Province: "The defence industrial participation projects will aggravate the dichotomies in the economy and not narrow them. Furthermore, to the extent they mobilise local capital into a fairly capitalintensive sector, they will actually limit employment creation" (COSATU 2001:3).

According to leading defence industry economists, strategic arms acquisitions are not an effective means of creating jobs. Harris (2000:9) argues that the price tag of the SAP, which is $\mathrm{R} 30$ billion, means that each of the promised 65000 jobs came at a price of R460 000 each. That same amount of money could employ between five and six educators or nursing staff .

Offsets have indeed been widely rejected as having enough economic impact to alleviate the negative impact of arms purchases on the economy. Offsets are therefore nothing more than empty promises. Critics argue that offsets actually increase the price of arms acquisition, are very difficult to monitor and provide opportunities for corruption (Crawford-Browne 2002:2). What has been accepted by many economists is that offsets via arms purchases can have a positive impact on 
economic growth - but such growth is very different to economic development. The former refers to a monetary increase in the size of a nation's economy as measured by the GDP, while the latter is more complex and intense and takes into consideration more relevant things such as distribution of economic benefits and access to resources (Dumas 2002:3; Dunne 2006:43).

Regardless of the critical consensus about offsets, SA's political and business leaders simply believe that foreign arms procurement can be a vehicle for economic growth. This belief is nothing new and has been held by many other countries in similar stages of economic development, for instance Brazil (Freeman 2002:3). This view sees growth in two ways. First, the local arms industry expands as a result of foreign investment, licensing and co-production. Second, local arms companies acquire foreign markets in which to promote their products. Governments prefer to spend domestically and offsets provide them with a means to channel funds back into the domestic economy. Moreover, the international tendency is that countries align politically and economically with those countries from whom they purchase expensive armaments (Jones 2001-2002:108). Thus, much of the Strategic Arms Package had to do with industry-military alliances or, stated differently, the militaryindustrial complex in South Africa. The ANC government views these alliances, along with minerals and energy, as a strategic vehicle with which to drive economic growth. There is little consideration that offsets' touted investments are investments that would have taken place without the SAP, or that the merger between DENEL, British Aerospace and Thomson CSF would most definitely have occurred without the carrot of the SAP. The latter two companies needed the merger more than DENEL, given the contraction within the international arms industry (Dunne 2002:5).

Perhaps the SA political and business elite's belief in arms purchases can be explained by the structure of the SA economy, which is still dominated by the mining and energy sectors. Offsets do not provide investment in housing, medical centres, schools or in the agricultural sector. Then again, the biggest recipient of non-military industrial participation attached to the SAP has been the minerals and energy sector attached to SA's military-industrial complex.

It is unreasonable to dismiss the offsets as empty promises but surely, the positive implications for the South African economy and average citizen have been grossly exaggerated. Moreover, it is impossible to accept the SAG's argument that the SAP will benefit the country as a whole. The SAP's offsets do serve the interests of some more than others. 


\section{1}

\section{Conclusion}

The pre-1994 negotiations between the old SADF and the MK resulted in an understanding that the SANDF would be rearmed in exchange for the military's support for a transition to democracy. The DoD, and especially the SAN, later lobbied the post-Apartheid regime for rearmament and eventually the SAP.

The Defence White Paper (1996), Defence Review (1998) and other government legislation require of the military to act constitutionally and of the DoD to pursue its acquisitions policy within the general framework of the state's financial policy. The DoD is obligated to keep costs to a minimum given South Africa's socio-economic problems. It failed in this regard, as there were cheaper alternatives to the Hawk, and the submarines and Gripens were an extravagance.

The executive, who took an active role in the selling of the SAP, promised the creation of 65000 jobs, though most of those jobs are within a capital-intensive and high skills defence industry, thus leaving the unskilled and unemployed out of the equation. FDI was also used as a carrot to manufacture legitimacy for the SAP, even though there is no guarantee that foreign companies will pay up or that their investment is actually in any way related to the SAP. If benefits do arrive, it will be to those already in economically dominant positions. However, the SAP, so the political and business elite simply assert, will be a good economic thing, could give SA more status within the international community and enable the country to become the West's main partner in security in Africa.

Parliament did in fact approve the Defence Review, including a force design with a defensive posture and conventional core force. Claims by the SAG and DoD that this is tantamount to an approval of the Arms Deal are false. Parliament approved of an ideal design given financial constraints. Parliament was not informed enough and Parliament's approval was prompted by pressure from the DoD and foreign arms companies. Although not all parliamentarians were convinced, critics were punished, and party discipline and the list electoral system ensured that MPs supported the executive's plans. ${ }^{13}$ MPs were also impressed by the promised offsets in the form of employment and FDI. The SAP was covered by developmental rhetoric, emphasising job creation and economic growth. Many were seduced by these arguments but in the end, such arguments hold little, if any, water.

${ }^{13}$ See for example Feinstein (2007:204). 
Both the domestic and international defence industries have lobbied Parliament and the SAG since the early days of South Africa's new democracy. Local arms companies have succeeded in receiving FDI and defence technology, as well as a foothold in the international arms market. Foreign firms like BAE were able to invest locally, thus securing for themselves an enormous advantage in any future arms contracts with South Africa.

Our analysis concentrated on the military necessity and affordability of the SAP. What does our discussion reveal about civil-military relations in democratic SA? What kind of decisions were made, and how? What of the decision itself?

The DoD, the Presidency and other role players have tried to legitimate their decision on the grounds of constitutional entitlement and the Defence Review, yet both arguments are unable to bear the weight of close examination. We have not quarrelled with the principle that the SA military should be modernised; instead, we have argued against the Arms Deal equipping the SANDF for the most improbable of missions. The SANDF's conventional defence against external threat, although constitutional and crucial in keeping the military out of politics, is a distant military possibility. The SANDF is heavily involved in secondary missions of peace operations and support of the SAPS (South African Police Services). It would have been sensible to choose items useful to both missions and to save on the price of the armaments in order to improve human resources.

The economic enthusiasm about the SAP can be seen pessimistically as an opportunity for government and dominant business and industry business to wed their interests in a way that is not much different from the National Party's militaryindustry alliances during apartheid. Otherwise, looking on the bright side of things, perhaps it just is that SA's citizens and its elites are extraordinarily naïve about development rhetoric or alternatively, that development rhetoric is an extraordinarily powerful almost magical tool in SA politics. Cover the Arms Deal with talk of FDI, growth, and jobs and people are prepared to buy it for R90 billion rand.

Regardless of our criticisms, one might think that the decision shows that there is a government commitment to modernise the SA military and that an immense amount of resources are available to that end. Our discussion of how the decision was made, suggests otherwise.

First, it is possible that the decision about the SAP had little to do with current government commitments; the decision was, rather, a consequence of a past 
"accident" or forced compromise during the transition to a democratic SA. Fearing the SADF's power to ruin the transition, the SADF's demands, including those of modernisation to undo the damage done by arms embargoes and sanctions, had to be met. Decisions to placate or buy off the SADF with the promise of armaments may well have been, at the time, unavoidable and could have set in motion a chain of events leading to the SAP. However, this chain of events does have an end and that end will come when the armaments arrive and the money is spent.

Second, given the pending charges and the concluded proceedings about corruption, ${ }^{14}$ surely the SAP deal is about weakness. The full extent of how tempting the bribes were for some politicians, their advisers, and DoD staff remains to be legally seen. However, its impact cannot but weaken the supposed political commitment to modernise. Future politicians and soldiers may well look at arms acquisitions and wonder whether they will be the "fall guy". The most obvious policy lesson of the SAP is that future decisions and decision-makers will have to pass through the very small eye of the ethical needle.

Third, the key promoters of the SAP have been in the executive branch and the Presidency, and their ability to get their way reveals the degree to which power within government has been centralised. This was evident from, among others, the marginalisation of Parliament and the punishment meted out to critics of the SAP, including critics within the ruling party. So it can be about political commitments, but this would be only those of a handful of people. The executive's dominating role in the SAP is strongly reminiscent of the PW Botha era in SA's civil-military relations. The difference is that, in democratic SA, presidential political commitment - whatever that is - has a term limit. Once the next president arrives, who knows what will happen to the idea that SA has to impress international organisations, dominate Africa's security, etc.

R29 billion is a huge commitment and does, at first glance, suggest a reliable and strong political will to modernise SA's military. Yet the way that decisions were made, in our view, suggests that such a political commitment does not exist. We will learn more, however, once the corruption trials and other legal proceedings are concluded. Civil-military relations researchers are in for exciting times.

\footnotetext{
${ }^{14}$ Here we refer to the cases of former JSCD (Joint Standing Committee of Defence) chairman Tony Yengeni and the Schabir Shaik trial. At the time of writing, the Jacob Zuma trial is yet to begin.
} 


\section{4}

\section{Bibliography}

Botha, D. 2003. "The arms deal controversy", African Security Review, 12:3. Available: http://www.iss.co.za/pubs/asr/12No3/C2.html [2008, 12 May].

Botha, D. 2003. "Offsetting the costs of SA's strategic defence package", ISS Paper, 75 , July.

Cawthra, G. 2000. Reconceptualising Security for the Twenty-First Century: South Africa's Experience in Remaking Defence. Buenos Aires: Universidad Torcuato Di Tella, September.

Cawthra, G. n.d. Security governance in South Africa. Paper for the Security Governance Project. Johannesburg: Friedrich Ebert Stiftung.

COSATU. 2001. The Arms Deal and Employment Creation. Submitted to the Portfolio Committee on Trade and Industry, 6 February.

Crawford-Browne, T. 2003. ECAAR-SA will Release BAeSystems Arms Deal Loan Agreements on Monday, September 22 at 10:30 am, Press Statement by ECAAR, 19 September.

Crawford-Browne, T. 2002. Offsets and the Affordability of the Arms Deal, Cape Town. Economists Allied for Arms Reduction, November. Available: http://www.ecaar.org/za/Papers/Offsets.htm [2008, 08 May].

Dumas, L. 2002. Weapons Procurement and Development: Do Offsets Mitigate or Magnify the Military Burden? Paper presented at the International Conference on Defence Offsets and Economic Development. 25-27 September, Cape Town.

Dunne, P. 2002. The Economics of South Africa's Defence Offsets. Paper presented to the International Conference on Defence Offsets and Economic Development. 2527 September, Cape Town.

Dunne, P. 2006. "The Making of Arms in South Africa", The Economics of Peace and Security Journal, 1(1):40-48. 
Engelbrecht, L. 2001a. South Africa's multi-billion arms programme revisited: Part One. Defence Systems Daily. 15 October. Available: http://defencedata.com/features/fpage45.htm [2008, 08 May].

Engelbrecht, L. 2001b. South Africa's multi-billion arms programme revisited: Part Two. Defence Systems Daily. 19 November. Available: http://defencedata.com/features/fpage47.htm [2008, 08 May].

February, J. 2004. South Africa - Democracy and the South African Arms Deal. Three Strikes against Graft, Commissioned case study for the ISS Anti-Corruption Strategies Programme. South Africa: Institute for Security Studies, 15-17 March.

Feinstein, A. 2007. After the Party. Cape Town: Jonathan Ball Publishers.

Ferreira, R. and Liebenberg, I. 2004. "Civil-military relations and arms procurement in South Africa: 1994-2002”, Society in Transition. 35:61-86.

Frankel, P. 2000. Soldiers in a Storm: The Armed Forces in South Africa's Democratic Transition. Boulder: Westview Press.

Freeman, S. 2002. Offsets and the Development of the Brazilian arms industry. Presented at the International Conference on Defence Offsets and Economic Development. 25-27 September, Cape Town.

Harris, G. 2000. The Irrationality of South Africa's Military Expenditure. Durban: University of Natal.

Institute for Security Studies (ISS). 2004. Submission on the South African Defence Review to the Portfolio Committee on Defence. 4 October, Pretoria: ISS.

Jacobs, S. and Calland, R. (eds.) 2002. Thabo Mbeki's World. Pietermaritzburg: University of Natal Press.

Jones, W. 2001-2002. "The value of military industrial offsets", DISAM Journal. Winter. 


\section{6}

Landsberg, C. and Adebajo, A. 2003. South Africa and Nigeria as Regional Hegemons, in M. Baregu and C. Landsberg (eds.). Cape To Congo: Southern Africa's Evolving Security Challenges. Boulder: Lynne Rienner.

Leigh, D. 2002. "The sordid truth behind an arms deal", The Guardian (UK), 17, July.

Le Roux, L. and Boshoff, H. 2005. The State of the Military, in J. Daniel, R. Southall and J. Lutchman (eds.). The State of the Nation. Pretoria: HSRC Press.

Mattes, R. 2002. "South Africa: Democracy without the people?" Journal of Democracy, 13(1):22-36.

McEwan, G. 2002. Defence Offsets and the South African Aerospace Industry. Paper presented at the Conference on Defense Offsets and Economic Development. 25-27 September, Cape Town.

Miller, D. 1996. Export or Die: Britain's Defence Trade with Iran and Iraq. London: Cassell.

Mills, G. 2004. "The South African National Defence Force: Between downsizing and new capabilities", Naval War College Review, 52(1):78-99.

Modise, T. 2004. Parliamentary Oversight of the South African Department of Defence: 1994-2003, in L. le Roux, and M. Rupiya (eds.). Guarding the Guardians. Tshwane: Institute for Security Studies.

Nathan, L. 2001. "Parliamentary approval of original Defence Review was no mandate to buy weapons" Sunday Independent, 22 July.

Nathan, L. 2005. "Consistency and inconsistencies in South African Foreign Policy.” International Affairs, 81(2):361-372.

Patel, N. 2006. South African Corporate Expansion into Africa. Unpublished MA thesis. Cape Town: University of Cape Town. 
Republic of South Africa (RSA). 1996a. MODAC Investigation of Technology and Armament: Acquisition in the Department of Defence. Pretoria: Department of Defence.

Republic of South Africa (RSA). 1996b. White Paper on Defence. Pretoria: Government Printer.

Republic of South Africa (RSA). 1998. Defence Review. Pretoria: Government Printer.

Republic of South Africa (RSA). 2000. Standing Committee on Public Accounts, Fourteenth Report. Pretoria: Government Printer.

Shelton, G. 1998. South African Arms Sales to North Africa and the Middle East: Promoting Peace or Fuelling the Arms Race? Johannesburg: Foundation for Global Dialogue.

Skosana, X. 2002. Arms Control, South African Style: The Dynamics of post-1994 Arms Export Control Policy. Pretoria: Institute for Security Studies.

Sylvester, J. 2006. Legislative Control over the Military: A Critical Analysis of the Strategic Arms Package. Unpublished MA thesis. Cape Town: University of Cape Town.

Thum, U. 2003. South Africa's Preventive Diplomacy and its Involvement in Conflict Resolution in Africa. Unpublished honours independent project. Cape Town: University of Cape Town.

Williams, R. 2005. "Human security and the transformation of the South African national security environment from 1990-2004: Challenges and limitations", Journal of Security Management, March:1-18.

Wrigley, C. 2003. The South African Arms Deal: A Case Study in the Arms Trade. London: Campaign Against Arms Trade.

Zacarias, A. 1998. The South African Defence Industry and the New Thinking on Security. Johannesburg: The South African Institute of International Affairs. 